\title{
The impact of need for social affiliation and consumer relationship proneness on behavioral intentions : an empirical study in a hairdresser's context
}

Citation for published version (APA):

Bloemer, J. M. M., Odekerken-Schröder, G. J., \& Kestens, L. (2002). The impact of need for social affiliation and consumer relationship proneness on behavioral intentions : an empirical study in a hairdresser's context. METEOR, Maastricht University School of Business and Economics. METEOR Research Memorandum No. 059 https://doi.org/10.26481/umamet.2002059

Document status and date:

Published: 01/01/2002

DOI:

10.26481/umamet.2002059

Document Version:

Publisher's PDF, also known as Version of record

Please check the document version of this publication:

- A submitted manuscript is the version of the article upon submission and before peer-review. There can be important differences between the submitted version and the official published version of record.

People interested in the research are advised to contact the author for the final version of the publication, or visit the DOI to the publisher's website.

- The final author version and the galley proof are versions of the publication after peer review.

- The final published version features the final layout of the paper including the volume, issue and page numbers.

Link to publication

\footnotetext{
General rights rights.

- You may freely distribute the URL identifying the publication in the public portal. please follow below link for the End User Agreement:

www.umlib.nl/taverne-license

Take down policy

If you believe that this document breaches copyright please contact us at:

repository@maastrichtuniversity.nl

providing details and we will investigate your claim.
}

Copyright and moral rights for the publications made accessible in the public portal are retained by the authors and/or other copyright owners and it is a condition of accessing publications that users recognise and abide by the legal requirements associated with these

- Users may download and print one copy of any publication from the public portal for the purpose of private study or research.

- You may not further distribute the material or use it for any profit-making activity or commercial gain

If the publication is distributed under the terms of Article $25 \mathrm{fa}$ of the Dutch Copyright Act, indicated by the "Taverne" license above, 
THE IMPACT OF NEED FOR SOCIAL AFFILIATION AND CONSUMER RELATIONSHIP PRONENESS ON BEHAVIOURAL INTENTIONS

An empirical study in a hairdresser's context

Josée Bloemer $^{1}$, Gaby Odekerken-Schröder ${ }^{2}$, Leen Kestens ${ }^{3}$

Josée Bloemer, Full Professor of Marketing and Market Research at Limburgs Universitair Centrum, University Campus, Building D, 3590 Diepenbeek, Belgium, phone: +32 11268733 , fax: +32 11268700

e-mail: jose.bloemer@luc.ac.be

Gaby Odekerken-Schröder, Assistant Professor of Marketing and Market Research at Maastricht University, Tongersestraat 53, 6211 LM Maastricht, the Netherlands, phone: +31 43 3883618, fax: +31433884918

Leen Kestens, Graduate Student in Applied Economics at Limburgs Universitair Centrum, University Campus, Building D, 3590 Diepenbeek, Belgium. 
THE IMPACT OF NEED FOR SOCIAL AFFILIATION AND CONSUMER RELATIONSHIP PRONENESS ON BEHAVIOURAL INTENTIONS

An empirical study in a hairdresser's context

\begin{abstract}
This study investigates whether a consumer's need for social affiliation and a consumer's relationship proneness impact behavioural intentions (word-of-mouth communication, price sensitivity, repeat purchasing) towards a hairdresser's. Data were collected from a systematic sample of a hairdresser's consumers in Belgium. LISREL results revealed that need for social affiliation is a strong determinant of word-of-mouth communication and price sensitivity, while consumer relationship proneness has an indirect effect on price sensitivity via commitment. Important implications of the salient role of both constructs in determining behavioural intentions in a hairdresser's context are provided.
\end{abstract}


THE IMPACT OF NEED FOR SOCIAL AFFILIATION AND CONSUMER RELATIONSHIP PRONENESS ON BEHAVIOURAL INTENTIONS

An empirical study in a hairdresser's context

Introduction

Our model assesses the impact of 'need for social affiliation' and 'consumer relationship proneness', on 'behavioural intentions' in a hairdresser's context. Although the primary focus of our study is on the direct effect of need for social affiliation and consumer relationship proneness on behavioural intentions, the indirect effect through satisfaction and commitment will also be addressed. The focal constructs need for social affiliation and consumer relationship proneness are deemed to be important in this context as will be illustrated from the service encounter literature, the commercial friendship literature, the service quality literature, and the relationship marketing literature.

Recently, the effect of values such as need for social affiliation on behavioural intentions has been addressed in several studies. For instance Wharton and Harmatz (1995) show a direct effect of consumer values on consumer behaviour next to an indirect effect through attitudes. Durgee, Oçonnor and Veryzer (1996) propose a direct effect of consumer values on consumer behaviour in terms of product preferences. Shim and Eastlick (1998) show indeed that need for social affiliation has an indirect influence on the patronage of regional shopping malls through attitudes. 
Whereas Allen and Hung Ng (1999) show that consumer values direct the attention of a consumer in the direction of those products that are related to a particular value and that the evaluation of the product is also influenced by values of the consumer.

Despite the increasing attention for research on consumer values, the exact link between specific consumer values such as social affiliation and behavioural intentions, is still unclear and under-researched.

A recent study (Odekerken-Schröder, De Wulf and Schumacher 2001) introduced 'consumer relationship proneness' as a mediating variable between the impact of need for social affiliation and behavioural intentions. Consumer relationship proneness represents a personality trait that reflects a consumer's relatively stable and conscious tendency to engage in relationships with sellers of a particular product category. This study provides empirical evidence for the crucial role of this construct in investigating the relationship between social affiliation, social recognition, and buying behaviour in a German beauty product context.

The remainder of this article is structured as follows. We will start with the theoretical framework and hypotheses, followed by a description of the research design, the results, discussion, managerial implications and limitations.

Theoretical Framework and Hypotheses

We distinguish between two core elements in our conceptual model. The first element refers to need for social affiliation and consumer relationship proneness, reflecting parts of a consumer's personality. The second element represents behavioural 
intentions in terms of word-of-mouth communications, price sensitivity and repeat purchasing (Bloemer et al. 1999; Parasuraman et al. 1994). Moreover, as a third element we include satisfaction and commitment since they are generally recognized as core attitudinal constructs in retail and services research focusing on behavioural intentions.

Figure 1 gives a visual representation of our conceptual model.

Insert Figure 1 about here

Need for social affiliation

In line with the literature on interpersonal relationships, we define the need for social affiliation as a preference to be with other people and to engage in relationships (Barrick and Mount 1991; Buss and Plomin 1984; Cheek and Buss 1981; Sadowski and Cogburn 1997). People with a high need for social affiliation do not look for social rewards, but are rather intrinsically valuing the relationships with other people (Carver and Scheier 1992).

From a service encounter perspective, the need for social affiliation can easily be fulfilled in a hairdresser's context since high customer contact is required in this people-based service delivery process. This process enables customers to have encounters with the service provider as well as with other customers (Chase 1978; Lovelock 1983; Thomas 1978). 
From a commercial friendship perspective the concept of need for social affiliation has been referred to as sociability (Price and Arnould 1999) and can be considered as "a tendency to affiliate with others and to prefer being with others to remaining alone" (Cheek and Buss 1981, p. 330). Price and Arnould (1999) regard sociability as one of the factors potentially contributing to the formation of commercial friendships in a services setting. Especially in a hairdresser's context, consumers may be motivated to maintain relationships with service providers because of social factors such as social support and assistance to consumers (Bendapudi and Berry 1997; Gwinner, Gremler and Bitner 1998).

From the service quality literature, the SERVQUAL-dimensions reliability, responsiveness, assurance, and empathy also rely heavily on the social interaction between consumer and service provider (Zeithaml, Parasuraman and Berry 1990). The service of a hairdresser's is generally considered to be expressive rather than instrumental (Price and Arnould 1999). Therefore, it will be very difficult for a hairdresser's to deliver high quality services to consumers who dislike social contact. As a result, the need for social affiliation seems to be a minimal requirement for successful service delivery.

We expect need for social affiliation to directly influence behavioural intentions. In line with Wharton and Hamatz (1995) and Durgee et al. (1996), we expect need for social affiliation to be positively related to word-of-mouth communications and repeat purchasing, and to be negatively related to price sensitivity. Need for social affiliation can be established through spreading word-of-mouth communications to friends or acquaintances, through maintaining a relationship with a service provider even if 
prices are somewhat increasing, or through actual repeat purchasing. Therefore, we formulate the following hypotheses:

$\mathrm{H}_{1}$ : The higher the need for social affiliation the higher the level of word-of-mouth communications

$\mathrm{H}_{2}$ : The higher the need for social affiliation the lower the level of price sensitivity

$\mathrm{H}_{3}$ : The higher the need for social affiliation the higher the level of repeat purchasing

Consumer relationship proneness

In line with Odekerken-Schröder, De Wulf and Schumacher (2001), we define consumer relationship proneness as a personality trait that reflects a consumer's relatively stable and conscious tendency to engage in relationships with sellers of a particular product category. To the best of our knowledge consumer relationship proneness has only been investigated in product-oriented contexts (OdekerkenSchröder, De Wulf and Schumacher 2001). In response to this, the current study assesses the role of consumer relationship proneness in a service setting.

From a service encounter perspective, consumer relationship proneness can be expected to play a crucial role in a hairdresser's context, since such a people-based service encounter, is more appropriate to accommodate a consumers' relationship proneness than an equipment based service encounter. 
From a commercial friendship perspective, a hairdresser frequently becomes an informal source of social support and assistance to clients with personal problems, favoring friendship formation between service providers and customers, including regular contact, interdependent outcomes, and the need to cooperate in producing them (Price and Arnould 1999). Therefore, the context of a hairdresser's provides a fruitful environment for people who are relationship prone and want to engage in relationships with service providers.

In a relationship marketing context, Shani and Chalasani (1992, p. 44) defined relationship marketing as an "effort to identify, build, and sustain a network of individual consumers, and the continuous strengthening of this network in the advantage of both parties by means of interactive, personal, and value-adding contacts during a long period". Given the need of both parties to maintain a relationship, supports the idea that relationship proneness of a consumer impacts behavioural intentions, also in a hairdresser's context.

Initial attempts have been made to investigate the impact of consumer relationship proneness on behavioural intentions (Beatty et al. 1996; Ellis 1995). In a recent empirical study Odekerken-Schröder, De Wulf and Schumacher (2001) showed, that consumer relationship proneness has a significant, positive indirect impact on buying behaviour. In line with this study, we formulate the following hypotheses:

$\mathrm{H}_{4}$ : The higher a consumer's relationship proneness, the higher the level of word-ofmouth communications 
$\mathrm{H}_{5}$ : The higher a consumer's relationship proneness the lower the level of price sensitivity

$\mathrm{H}_{6}$ : The higher a consumer's relationship proneness the higher the level of repeat purchasing

Although hardly any empirical research is available on the effect of need for social affiliation in buyer-seller relationships (Ellis 1995), we expect that it plays a substantial role in strengthening a consumer's relationship proneness. Consequently, we formulate the following hypothesis:

$\mathrm{H}_{7}$ : The higher need for social affiliation the higher the level of consumer relationship proneness

Satisfaction and commitment

The prime interest of this study is to assess the direct effects of need for social affiliation and consumer relationship proneness on behavioural intentions. However, based on existing research the indirect effects via satisfaction and commitment should not be overlooked.

It is generally recognized that a consumer's satisfaction is dependent upon the efforts made by the retailer. However, there are reasons to assume that satisfaction is not 
merely dependent upon a retailer's actions, but also upon a consumer's need for social affiliation and relationship proneness.

We expect need for social affiliation to affect satisfaction positively, as this can be considered as a personality trait stimulating relationships with retailers. Forman and Sriram (1991) claimed that people in search for human contact are willing to engage in long-term relationships. Moreover, Storbacka, Strandvik, and Grönroos (1994) stated that consumers who are interested in relationships perceive satisfaction with a relationship to be important. This might imply that relationship prone consumers could be more easily satisfied as a result of a higher receptivity towards a retailer's efforts aimed at enhancing the relationship. In line with Oliver (1997, p. 13) we perceive satisfaction as a post-consumption evaluation or "a pleasurable level of consumption-related fulfillment". Therefore, we posit the following hypotheses:

$\mathrm{H}_{8}$ : The higher need for social affiliation the higher the level of satisfaction

$\mathrm{H}_{9}$ : The higher the level of consumer relationship proneness the higher the level of satisfaction

Need for social affiliation can be considered to stimulate relationships with retailers. Support can be found that consumer relationship proneness also influences commitment (Odekerken-Schröder 1999). However, relatively little empirical work exists that aims at explaining why individual characteristics such as consumer relationship proneness should be related to commitment (Mathieu and Zajac 1990). In 
conceptual research, individual characteristics have generally been considered as antecedents of commitment (Mathieu and Zajac 1990; Rylander, Strutton, and Pelton 1997). Individuals are generally committed to sellers that fulfil underlying needs of these individuals (Korgaonkar, Lund, and Price 1985; Mathieu and Zajac 1990). Storbacka, Strandvik, and Grönroos (1994) further indicated that a consumer's interest in relationships influences the level of commitment to a relationship in which the consumer is engaged. Commitment can be defined as "a buyer's enduring desire to continue a relationship with a seller accompanied by his willingness to make efforts at maintaining it" (Morgan and Hunt 1994). We posit the following hypotheses.

$\mathrm{H}_{10}$ : The higher need for social affiliation the higher the level of commitment

$\mathrm{H}_{11}$ : The higher the level of consumer relationship proneness the higher the level of commitment

Several authors hypothesize a positive path from relationship satisfaction to constructs indicating commitment (Bolton 1998; Ganesan 1994; Macintosh and Lockshin 1997; Ping 1993). Ganesan (1994) found strong empirical support for the path from satisfaction to long-term orientation. In line with this, our research model posits an effect of satisfaction on commitment. Our rationale for this is of a conceptual nature, meaning that we consider commitment as an aggregate evaluation resulting from satisfaction.

$\mathrm{H}_{12}$ : The higher the level of satisfaction the higher the level of commitment 
Considerable conceptual and empirical evidence support the notion that commitment is the ultimate attitudinal outcome in relationships with causal precedence of relationship satisfaction. As a desire and willingness to act imply higher chances of behavioural intentions, we assume that there exists a positive relationship between commitment and behavioural intentions. Some support can be found in literature regarding this assumption. Several authors support the notion that commitment motivates buyers to act (Gruen 1995; Hennig-Thurau and Klee 1997; Mathieu and Zajac 1990). Liljander and Strandvik (1993) concluded that commitment and behavioural intentions are related concepts. Morgan and Hunt (1994) found significant relationships between the level of a buyer's commitment and his acquiescence, propensity to leave, and cooperation, all of which can be regarded as behavioural intentions. Several organizational commitment studies focused on the intent to leave and turnover as primary behavioural intentions (Rylander, Strutton, and Pelton 1997). Moorman, Zaltman, and Desphandé (1992) suggested that buyers who are committed to a relationship might have a greater propensity to act because of their need to remain consistent with their commitment. Finally, Dick and Basu (1994) stated that the stronger commitment, the more likely the buyer is to overcome potential obstacles in the buyer-seller relationship, resulting in repeat patronage.

Building upon Bloemer et al. (1999) and Zeithaml et al. (1996) we prefer to distinguish between three different types of behavioural intentions: word-of-mouth communications, price sensitivity and repeat purchasing.

Based on these insights, we formulate the following hypotheses: 
$\mathrm{H}_{13}$ : The higher the level of commitment the higher the level of word-of-mouth communications

$\mathrm{H}_{14}$ : The higher the level of commitment the lower the level of price sensitivity

$\mathrm{H}_{15}$ : The higher the level of commitment the higher the level of repeat purchasing

Research Design

Data collection

We sought to select a service context in which a service provider and a consumer can show their preference to be with other people and to engage in relationships. Therefore, we studied the customers of a hairdresser's. This service delivery process is highly interactive requiring inputs from both hairstylist and customer; involves intimate proximity; is relatively extended in duration; is affectively charged; and is repeated at semi regular intervals over time. Each of these factors enhances the likelihood that the need for social affiliation can be fulfilled and that a consumer can display his/her relationship proneness.

Our sample enables us to discover whether need for social affiliation and consumer relationship proneness affect behavioural intentions, rather than being a representative sample covering the complete population of hairdressers and their consumers.

Data were collected from a systematic sample (every $5^{\text {th }}$ consumer) of a hairdresser's consumers in a mid-sized town in the Flemish part of Belgium. During the last weeks of 1999 and the first weeks of 2000 customers were asked to fill out the questionnaire. 
Consumers completed the questionnaire immediately following their appointment. One hundred and eighty five correctly filled out questionnaires were collected. The sample was found to be representative for the customers of the hairdressers' in terms of gender, age, longevity of the relationship and the frequency by which the customer visits the hairdresser's.

Measurement instrument

The measurement instrument was based on various valid and reliable scales. Social affiliation was measured with the 3-item factor of Shim and Eastlick (1998) which was labelled 'social affiliation'. These 3 items originated from the List of Values (LOV) of Kahle (1983). We used a 7-point scale reaching from very unimportant to very important. Relationship proneness was measured with a 3-item instrument being validated and tested by Odekerken-Schröder, De Wulf and Schumacher (2001). Here, also a 7-point scale was used reaching from completely disagree to completely agree. Satisfaction was operationalized within Oliver's (1997) framework by using 8 statements on a 7-point scale that also reached from completely disagree to completely agree (Bloemer en De Ruyter 1998). Commitment was measured with a 3item validated scale (Beatty, Homer and Kahle 1988). Here also a 7-point scale was used that reached from completely disagree to completely agree. Finally, word-ofmouth communication, price sensitivity, and repeat purchasing were operationalized according to Zeithaml etl. (1996). All original items for the 3 aspects of behavioural intentions were used and scaled on a 7-point scale reaching from very unlikely to very likely. 
Although the reliability of all scales used has been tested in previous research, we conducted an exploratory factor analysis to assess the reliability of the scales in the current context. This resulted in excluding items revealing a factor score lower than 0.60 on the intended factor or a factor score higher than 0.30 on unintended factors. Ultimately, the scales for need for social affiliation, consumer relationship proneness, satisfaction and word-of-mouth communication were included completely. We had to remove one item from the scales for commitment, price sensitivity and repeat purchasing.

Results

In order to test our conceptual model, structural equation modelling with unobserved variables was conducted using maximum likelihood estimation in LISREL 8.3. A variance-covariance matrix was calculated using LISREL's companion program PRELIS and was used as input for the path analyses. We subsequently analysed the overall model, the measurement model and the structural model.

In the overall model, the chi-square value is significant (450.42 with 215 degrees of freedom), a finding not unusual with large sample sizes (Doney and Cannon 1997). The ratio of chi-square to degrees of freedom is 2.09 , which can be considered as adequate. The values of GFI (0.82) and AGFI (0.77) are somewhat lower than those of CFI (0.92), IFI (0.92) and NNFI (0.90). This result is mainly due to the former measures being more easily affected by sample size and model complexity. In general, the indicated fits are good, including RMSEA, which is 0.078, and SRMR, being 0.080 . Given the adequacy of these indices, given the fact that the model was 
developed on theoretical bases, and given the relative complexity of the model, no model re-specifications were made.

We assessed the quality of the measurement model on unidimensionality, convergent validity, reliability, and discriminant validity. Evidence for the unidimensionality of each construct was based upon a principal components analysis revealing that the appropriate items loaded at least 0.60 (except for the item of need for social affiliation, and one item of consumer relationship proneness) on their respective hypothesized component, with a loading no larger than 0.30 on other components. Convergent validity was supported by a good overall model fit, all loadings being significant $(\mathrm{p}<0.01)$, and the majority of $\mathrm{R}^{2}$ exceeding 0.50 (Hildebrandt 1987). Reliability was indicated by composite reliability measures all exceeding 0.70 . Discriminant validity was tested in a series of nested confirmatory factor model comparisons in which correlations between latent constructs were constrained to 1 , and indeed chi-square differences were significant for all model comparisons $(\mathrm{p}<$ 0.01). In addition, the average percentage of variance extracted for nearly all constructs was greater than 0.50 . In sum, the measurement model is clean, with evidence for unidimensionality, convergent validity, reliability, and discriminant validity (Table 1).

Insert Table 1 about here

Figure 2 and Table 2 contain the detailed results related to the structural model. 
The direct effect of need for social affiliation on word of mouth $\left(\mathrm{H}_{1 \text { supported }}\right)$ and price sensitivity $\left(\mathrm{H}_{2} \text { supported }\right)^{1}$ could be confirmed, whereas the path from need for social affiliation to repeat purchasing was not significant $\left(\mathrm{H}_{3}\right.$ not supported $)$. The direct effect of consumer relationship proneness on behavioural intentions was not significant $\left(\mathrm{H}_{4}\right.$ not supported, $\mathrm{H}_{5 \text { not supported, }} \mathrm{H}_{6}$ not supported). The direct effect of need for social affiliation on consumer relationship proneness could be confirmed $\left(\mathrm{H}_{7}\right.$ supported $)$. The impact of need for social affiliation on satisfaction $\left(\mathrm{H}_{8}\right.$ supported $)$ could be supported while the impact of consumer relationship proneness on satisfaction $\left(\mathrm{H}_{9}\right.$ not supported $)$ could not be confirmed. We could neither confirm the impact of social affiliation on commitment $\left(\mathrm{H}_{10}\right.$ not supported $)$ as this effect was negative as opposed to the hypothesized positive impact. However, we could confirm the impact of consumer relationship proneness on commitment ( $\left.\mathrm{H}_{11 \text { supported }}\right)$. The effect of satisfaction on commitment $\left(\mathrm{H}_{12}\right.$ supported $)$ could be confirmed. Finally the impact of commitment on all the behavioural intentions distinguished could also be supported ( $\left.\mathrm{H}_{13 \text { supported }}, \mathrm{H}_{14 \text { supported }}{ }^{1}, \mathrm{H}_{15 \text { supported }}\right)$.

In order to gain better insight into the decomposition of the structural effects Table 3 reports the direct, indirect and total effects from need for social affiliation and consumer relationship proneness to word-of-mouth, price-sensitivity and repeat purchasing. The table shows, that in general, in addition to the previously reported direct effect (1) social affiliation also has an indirect negative effect via satisfaction and commitment on word-of-mouth, (2) consumer relationship proneness has an indirect positive effect via satisfaction and commitment on price-sensitivity, (3) need 
for social affiliation has a negative indirect effect via satisfaction and commitment on price sensitivity.

Insert table 3 about here

\section{Discussion}

Motivated by service encounter literature, commercial friendship literature, service quality literature and relationship marketing literature, the purpose of this study was to investigate the effects of need for social affiliation and consumer relationship proneness on behavioural intentions in a hairdresser's context. Our results are remarkable, mainly due to the number of hypotheses that could not be supported by our findings. Although, we found strong support for the impact of the need for social affiliation on word-of-mouth communication and price sensitivity and of relationship proneness on commitment, we have to conclude that the direct impact of consumer relationship proneness on behavioural intentions in a hairdresser's context is rather limited.

Although the existing literature indicates that social affiliation is positively related to word-of-mouth communication, price sensitivity, and repeat purchasing, our results do not confirm the latter. It seems that social affiliation and repeat purchasing are not related to one another implying that other factors will determine the extent of repeat purchasing behaviour.

Consumer relationship proneness apparently fulfils a different role in a hairdresser's context than in a product context such as the beauty product context in OdekerkenSchröder, De Wulf, and Schumacher (2001). While consumer relationship proneness

\footnotetext{
${ }^{1}$ One item of price sensitivity was recoded, implying that a positive coefficient means
} 
is a strong determinant of commitment and indirectly of price sensitivity, it does not have a direct impact on behavioural intentions in our study. A potential explanation might be that the heterogeneity of the service delivery process in a hairdresser's context implies that a consumer's relationship proneness will be satisfied to a different extent each time and again, while a more stable fulfilment of a consumer's relationship proneness can be expected in a product context.

The difference in impact of consumer relationship proneness and need for social affiliation might be due to the distinct nature of both constructs. While fulfilment of a consumer's relationship proneness is mainly dependent upon the service provider and the service delivered by the service provider, fulfilment of a consumer's need for social affiliation is also strongly influenced by the social support of and social interaction with other customers visiting the hairdresser's.

We could not support the path from social affiliation to commitment. Although we expected a positive relationship, the data reveal a negative relationship. As opposed to our previous expectations, social affiliation does not seem to be a personality trait stimulating commitment to one particular hairdresser's. Nevertheless, it has a positive influence on relationship proneness, which focuses on a general willingness to engage in relationships with retailers. A potential reason underlying this idea might be that this consumer does not want to express his bond to a particular hairdresser's in his attitude, since he still appreciates the idea of freedom of choice.

\section{Managerial implications}

Our study is valuable from a managerial point of view. Our data support the belief that a personality trait, such as need for social affiliation and consumer relationship

a lower level of price sensitivity. 
proneness, affect word-of-mouth and price sensitivity (Storbacka, Strandvik, and Grönroos 1994). Woodside and Trappey III (1996) already referred to the value of performing customer portfolio analysis for developing a better understanding of why customers buy. While need for social affiliation and relationship proneness cannot be controlled by the retailer, segmenting consumers according to levels of need for social affiliation and consumer relationship proneness could affect expected share-of-market and share-of-customer values, given that social affiliated consumers and relationshipprone consumers have a higher tendency to act upon their need for social affiliation and consumer relationship proneness. This is in line with a recent recommendation by Söllner (1999), stating that careful customer segmentation has to be carried out in order to identify clients who may appreciate to be loyal.

This means that a hairdresser's should attract consumers who have a high need for social affiliation by stimulating interclient relationships in for instance a coffee corner where customers can meet, social support, empathy and commercial friendships. Moreover, a hairdresser's could try to attract consumers who are relationship prone by creating an environment in which its customers have the opportunity to establish warm relationships with the hairdresser who will then be considered as someone who can offer personal attention, social support and comfort.

\section{Limitations}

Our research should be seen as a preliminary attempt at addressing an issue that has important implications for services and retail marketing theory and practice, more specifically in a hairdresser's context. Any preliminary attempt will involve a number of limitations. However, acknowledgement of these limitations also suggests new directions for future studies. 
This study showed that the construct of relationship proneness as well as the need for social affiliation are important antecedents of behavioural intentions. These results emphasize the importance of consumers' personality traits in the choices made in a hairdresser's context. As a result, future studies are suggested to incorporate these personality-related constructs. Moreover, we might also suggest incorporating other personality-related constructs such as for instance risk aversion and self-actualizing. Our study focused on behavioural intentions only and these intentions are an incomplete proxy for actual behaviour (Keaveney 1995). They should be supplemented by behavioural measures in order to develop a composite index of store loyalty (Dick and Basu 1994).

Next, the empirical relationships reported in this article are tentative in the sense that they are based on cross-sectional data collected at one moment in time. Longitudinal research that focuses on the dynamics of the different constructs over time is needed to define the exact causal nature of the link between the constructs.

Finally, for the purpose of cross-validation, additional exploration of the relationships needs to be extended beyond the current hairdresser's setting reported here. Further conceptual and empirical research addressing aforementioned topics may yield a more in-depth insight into the influence of personality traits on behavioural intentions through a deductive approach. 


\section{References}

Allen, W and Hung Ng, S (1999) 'The direct and indirect influences of human values on product ownership', Journal of Economic Psychology 20 5-39

Barrick, M R and Mount, M K (1991) 'The big five personality dimensions and job performance: a meta-analysis', Personnel Psychology 44 1-26

Beatty, S E, Mayer, M, Coleman, J E, Reynolds, K E and Lee, J (1996) 'Customersales associate retail relationships', Journal of Retailing 72 (3) 223-47

Beatty, S, Homer P and Kahle L (1988), 'The involvement-commitment model: Theory and Implications,' Journal of Business Research, 16 (2), 149-167

Bendapuri, N and Berry, L L (1997) 'Customers' motivations for maintaining relationship with service providers', Journal of Retailing 73 (1) 15-37

Bloemer, J and De Ruyter, K (1998) 'Customer loyalty in high and low involvement settings: The moderating impact of positive emotions', Journal of Marketing Management 315-330

Bloemer, J, Ruyter, de K and Wetzels, M (1999), 'Linking perceived service quality and service loyalty: a multi-dimensional perspective', European Journal of Marketing $33(11 / 12), 1082-1107$ 
Bolton, R (1998), ‘A Dynamic Model of the Duration of the Customer's Relationship with a Continuous Service Provider: The Role of Satisfaction', Marketing Science, 17 (1), 45-65

Buss, A and Plomin, R (ed) (1984) Temperament: Early Developing Personality Traits Erlbaum, Hillsdale: New York

Carver C S and Scheier, M F (ed) (1992) Perspectives on Personality Allyn and Bacon, Boston

Chase R W (1978) 'Where does the customer fit in a service operation?', Harvard Business Review 56 137-42

Cheek, J M and Buss, A H (1981) 'Shyness and sociability', Journal of Psychology and Social Psychology 41 (2) 330-39

Dick, A S and Basu, K (1994) 'Customer loyalty: toward an integrated conceptual framework', Journal of the Academy of Marketing Science 22 (2) 99-113

Doney, P M and Cannon, J P (1997) 'An examination of the nature of trust in buyerseller relationships', Journal of Marketing 61 (2) 35-51

Durgee, J F, O’Connor, G C and Veryzer, R W (1996) 'Observations: Translating values into product wants', Journal of Advertising Research 36 (6) 90-99 
Ellis, K (ed) (1995) The Determinants of the Nature and Types of CustomerSalesperson Relationships in a Retail Setting: An Empirical Study Doctoral Dissertation, University of Alabama

Forman, A M and Sriram, V (1991) 'The depersonalization of retailing: its impact on the 'lonely' consumer', Journal of Retailing 67 (2) 226-43

Gansesan, S (1994) 'Negotiation strategies and the nature of channel relationships', Journal of Marketing Research 58 (2) 183-203

Gruen, T (1995) 'The outcome set of relationship marketing in consumer markets', International Business Review 4 447-469

Gwinner, K, Gremler, D and M Bitner (1998) 'Relational Benefits in Services Industries: The Customer's Perspective', Journal of the Academy of Marketing Science, 26 (2), 101-114.

Hennig-Thurau, T and Klee, A (1997) 'The impact of customer satisfaction and relationship quality on customer retention: a critical reassessment and model development', Psychology and Marketing 14 (8) 737-64

Kahle, L R (ed) (1983) Social Values and Social Change: Adaptation of Life in America Praeger, New York 
Keaveny, SM (1995) 'Customer switching behaviour in service industries: an exploratory study', Journal of Marketing 59 71-82

Korgaonkar, P K, Lund, D and Price, B (1985) 'A structural equations approach toward examination of store attitude and store patronage behavior', Journal of Retailing 61 (2) 39-60

Liljander, v and Strandvik, T (1993) 'Estimating zones of tolerance in perceived service quality and perceived service value', International Journal of Service Industry Management 4 (2) 6-28

Lovelock, C H (1983) 'Classifying services to gain strategic marketing insights', Journal of marketing 47 (Summer) 9-20

Macintosh, G and Lockshin S (1997) 'Retail relationships and store loyalty: A multilevel perspective', International Journal of Research in Marketing 14 (5) 487-497

Mathieu, J E and Zajac, D M (1990) 'A review and meta-analysis of the antecedents, correlates, and consequences of organizational commitment', Psychological Bulletin 108 (2) $171-94$

Moorman, C, Zaltman, G and Desphandé, C (1992) 'Relationships between providers and users of market research: The dynamics of trust within and between organizations', Journal of Marketing Research 58 20-38 
Morgan, R M and Hunt, S D (1994) 'The commitment-trust theory of relationship marketing', Journal of marketing 58 (July) 20-38

Odekerken-Schroder, G, De Wulf K and Schumacher P (2001) 'Strengthening outcomes of retailer-consumer relationships: The dual impact of relationship marketing tactics and consumer personality', Journal of Business Research 55 1-14

Oliver, R (1997), Satisfaction. A Behavioral Perspective on the Consumer. New York: McGraw-Hill

Parasuraman, A P, Zeithaml, V A and Berry, L L (1994) 'Measuring different customer expectations levels, comparing alternative scales, and examining the performance-behavioral intensions link', Marketing Science Institute, working paper (September) 94-114.

Ping, R A (1993) 'The effects of satisfaction and structural constraints on retailer exiting, voice, loyalty, opportunism, and neglect', Journal of Retailing 69 (3) 320-52

Price, L L and Arnould E J (1999) 'Commercial friendships: service provider-client relationships in context', Journal of Marketing 63 38-56

Rylander, D, Strutton, D and Pelton, L E (1997) 'Toward a synthesized framework of relational commitment: implications for marketing channel theory and practice', Journal of Marketing Theory and Practice 5 (2) 58-71 
Sadowski, C J and Cogburn, H E (1997) 'Need for cognition in the big-five factor structure', The Journal of Psychology 131 (3) 307-12

Shani, D and Chalasani, S (1992) 'Exploiting niches using relationship marketing', Journal of Services Marketing 6 (4) 43-52

Shim, S and Eastlick, M A (1998) 'On mall shopping attitude and behavior', Journal of Retailing 74 (1) 139-160

Söllner, A (1999) 'Asymmetrical Commitment in Business Relationships', Journal of Business Research 46 219-233.

Storbacka, K, Strandvik, T and Grönroos, C (1994) 'Managing customer relationships for profit: the dynamics of relationship quality', International Journal of Service Industry Management 5 (5) 21-38

Thomas, D R E (1978) 'Strategy is different in service businesses', Harvard Business Review 56 158-165

Wharton, Z and Harmatz, H R (1995) 'Responses to the economy among two value orientation segments', Journal of Economic Psychology 16 205-222

Woodside, A G and Trappey R J III (1996) 'Customer portfolio analysis among competing retail stores', Journal of Business Research 35 (3) 189-199 
Zeithaml, V, Parasuraman, A, and Berry L (1990), Delivering Quality Service: Balancing Customer Perceptions and Expectations, New York: The Free Press

Zeithaml, V A, Berry, L L and Parasuraman, A (1996) 'The behavioral consequences of service quality', Journal of Marketing 60 (April) 31-46 


\section{FIGURE 1}

\section{Conceptual Model}

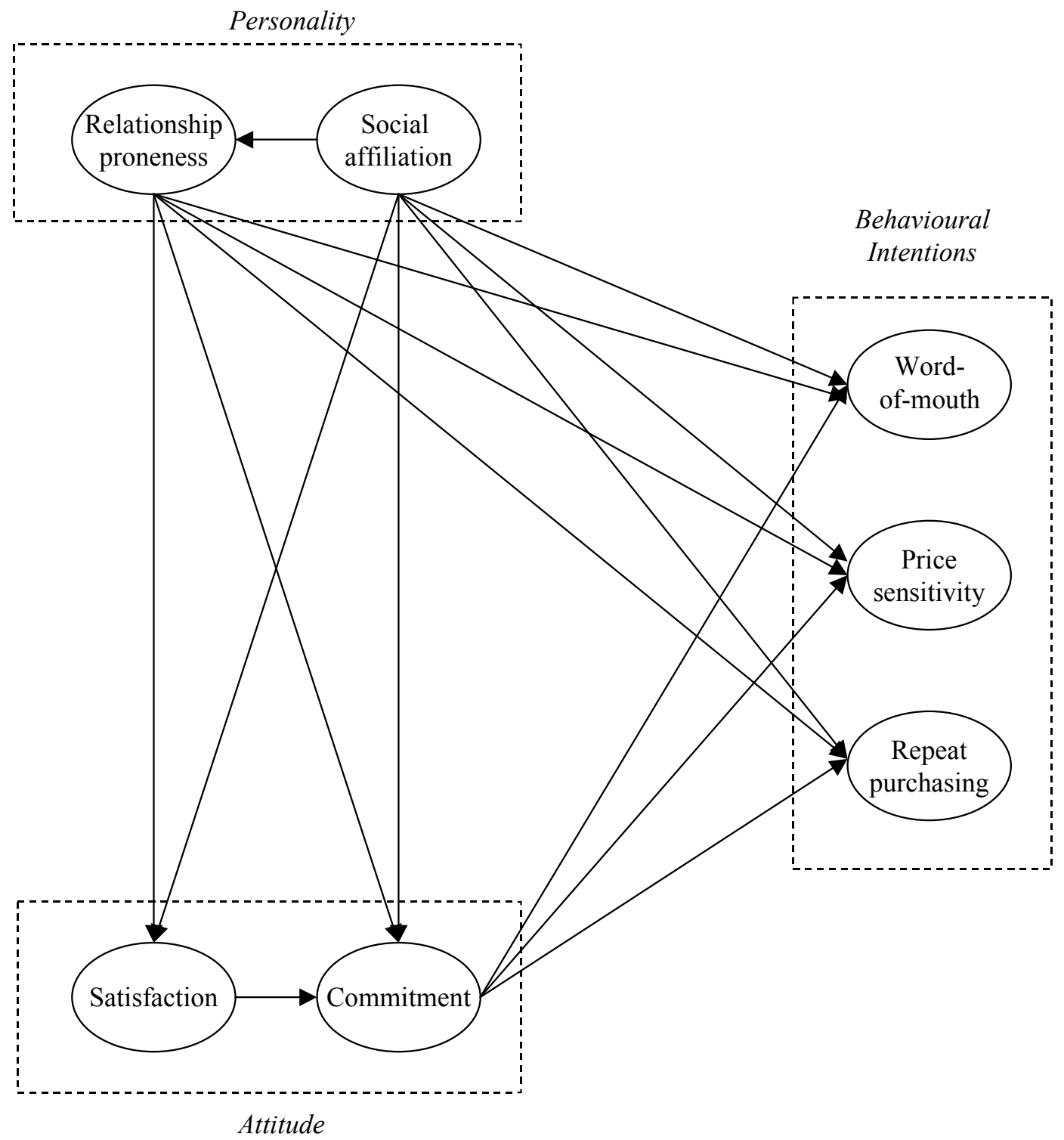


FIGURE 2

\section{Structural Model}

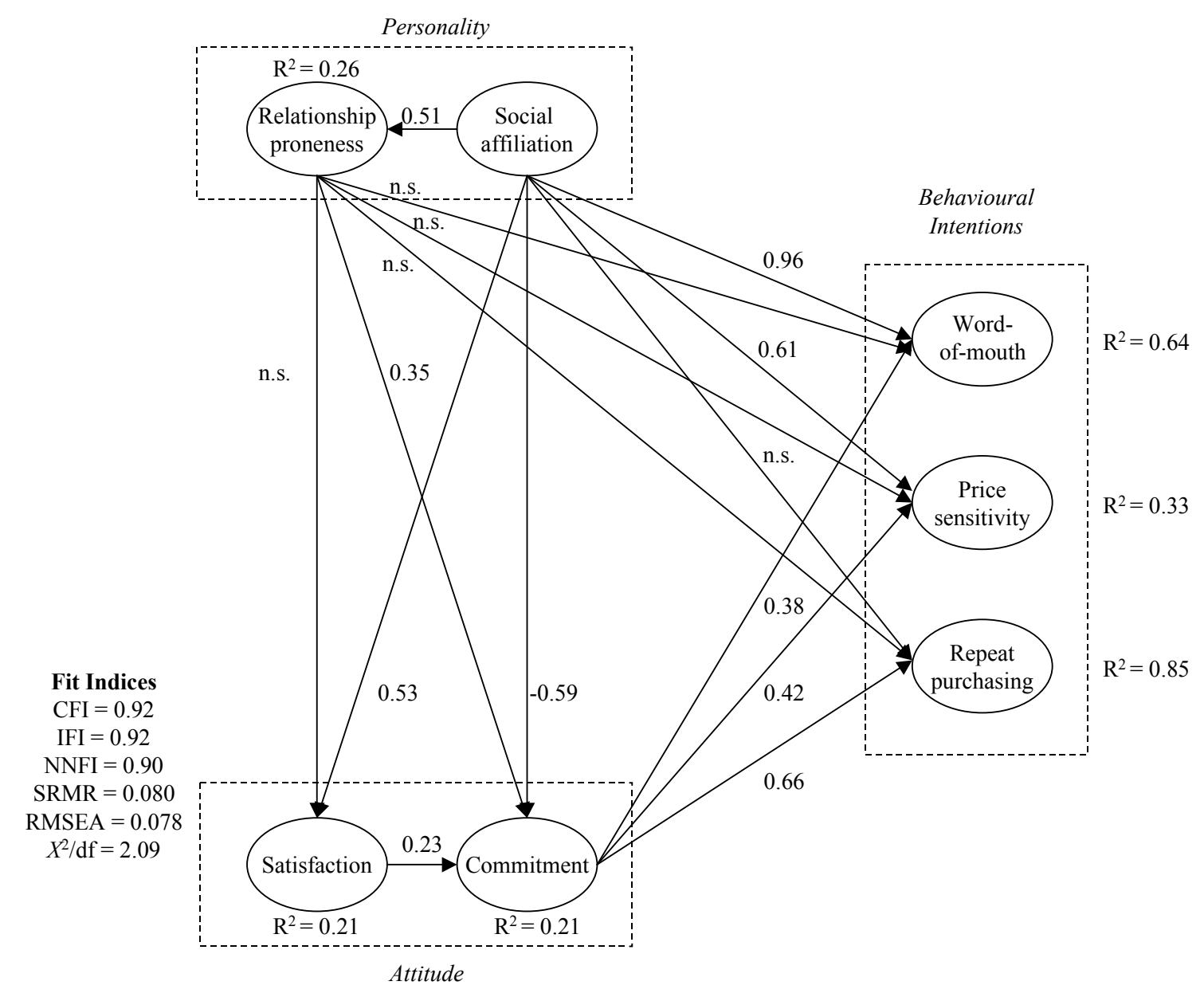


TABLE 1

Measurement Model

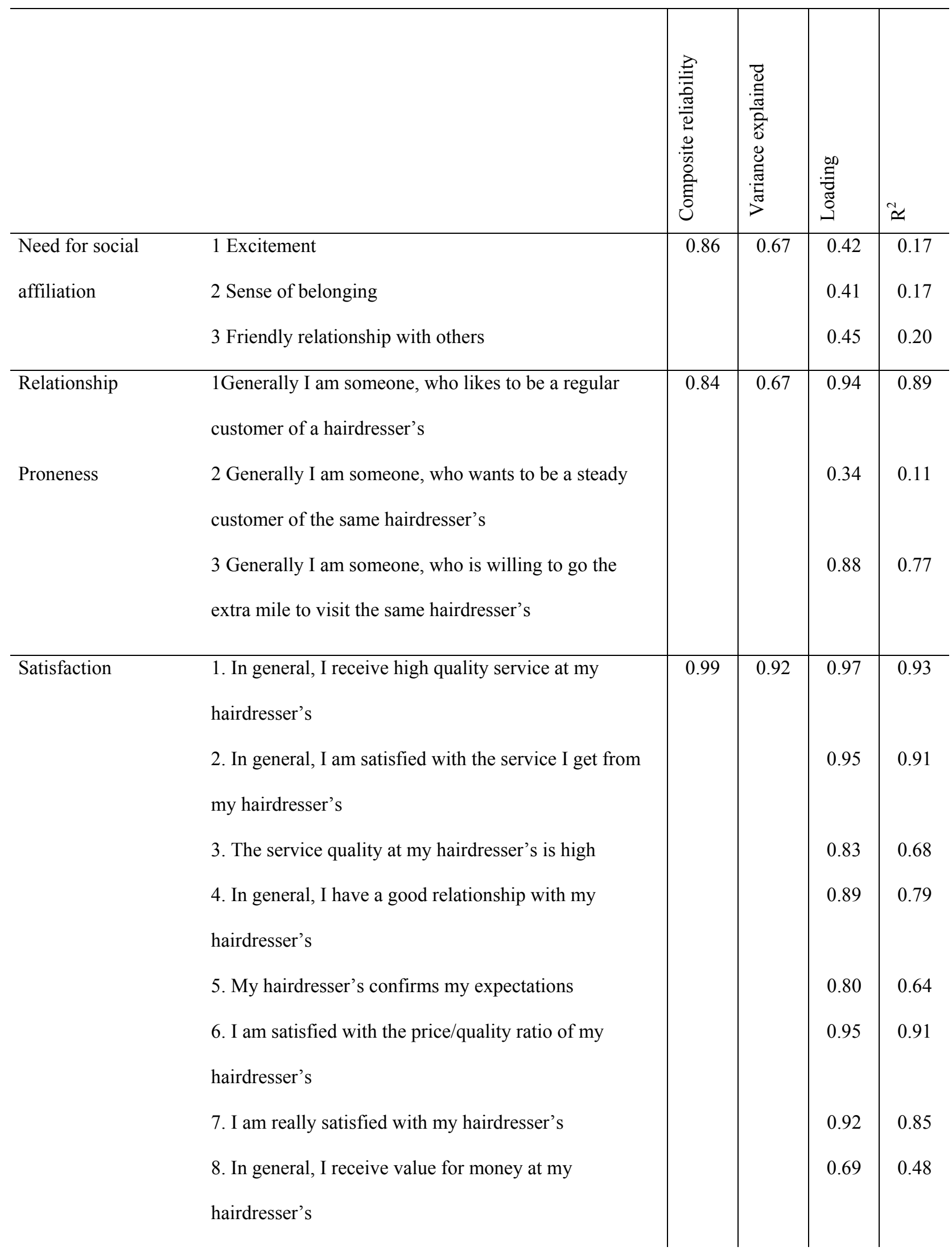




\begin{tabular}{|c|c|c|c|c|c|}
\hline Commitment* & $\begin{array}{l}1 \text { If my preferred hairdresser were not available, it } \\
\text { would make little difference to me if I had to choose } \\
\text { another hairdresser } \\
2 \text { When another hairdresser offers a discount, I will } \\
\text { generally go there, rather than to my regular hairdresser }\end{array}$ & 0.88 & 0.79 & 0.86 & 0.74 \\
\hline Word-of-mouth & $\begin{array}{l}\text { 1. I say positive things about my hairdresser's to other } \\
\text { people } \\
\text { 2. I recommend my hairdresser's to someone who seeks } \\
\text { advice } \\
\text { 3. I encourage friends to go to my hairdresser's }\end{array}$ & 0.93 & 0.82 & 0.85 & 0.47 \\
\hline Price sensitivity & $\begin{array}{l}\text { 1. I am willing to pay a higher price than other } \\
\text { hairdresser's charge for the benefits I currently receive } \\
\text { from my hairdresser's } \\
2 .^{*} \text { I am willing to go to another hairdresser's, that } \\
\text { offers more attractive prices }\end{array}$ & 0.91 & 0.85 & 0.89 & 0.79 \\
\hline Repeat purchasing & $\begin{array}{l}\text { 1. I consider my hairdresser's as my first choice } \\
\text { 3. In the near future I surely attend my hairdresser's } \\
\text { again }\end{array}$ & 0.74 & 0.58 & $\begin{array}{l}0.94 \\
0.88\end{array}$ & $\begin{array}{l}0.37 \\
0.08\end{array}$ \\
\hline
\end{tabular}

* items are recoded 
TABLE 2

\section{Structural Model}

\begin{tabular}{|c|c|c|c|}
\hline Parameter & $\begin{array}{l}\text { Hypo- } \\
\text { thesis }\end{array}$ & $\begin{array}{c}\text { ML } \\
\text { estimate }\end{array}$ & $\begin{array}{c}\text { T- } \\
\text { value }\end{array}$ \\
\hline Relationship proneness $\rightarrow$ word-of-mouth (H4) & No support & -0.25 & -1.73 \\
\hline Relationship proneness $\rightarrow$ price sensitivity (H5) & No support & -0.12 & -0.98 \\
\hline Relationship proneness $\rightarrow$ repeat purchasing behavior (H6) & No support & -0.41 & -0.70 \\
\hline Relationship proneness $\rightarrow$ satisfaction (H9) & No support & -0.19 & -1.83 \\
\hline Relationship proneness $\rightarrow$ commitment (H11) & Support & $0.35^{* *}$ & 2.42 \\
\hline Satisfaction $\rightarrow$ commitment (H12) & Support & $0.23 * *$ & 2.17 \\
\hline Commitment $\rightarrow$ word-of-mouth (H13) & Support & $0.38 * *$ & 2.90 \\
\hline Commitment $\rightarrow$ price sensitivity (H14) & Support & $0.42 * *$ & 3.89 \\
\hline Commitment $\rightarrow$ repeat purchasing (H15) & Support & 0.66 & 0.74 \\
\hline Need for social affiliation $\rightarrow$ word-of-mouth (H1) & Support & $0.96^{* *}$ & 4.18 \\
\hline Need for social affiliation $\rightarrow$ price sensitivity (H2) & Support & $0.61 * *$ & 4.24 \\
\hline Need for social affiliation $\rightarrow$ repeat purchasing (H3) & No support & 0.99 & 0.74 \\
\hline Need for social affiliation $\rightarrow$ relationship proneness $(\mathrm{H} 7)$ & Support & $0.51 * *$ & 3.65 \\
\hline Need for social affiliation $\rightarrow$ satisfaction (H8) & Support & $0.53 * *$ & 4.46 \\
\hline Need for social affiliation $\rightarrow$ commitment (H10) & No support & -0.59 & -2.70 \\
\hline Squared multiple correlations for structural equations & \multicolumn{3}{|c|}{ Estimate } \\
\hline Satisfaction & \multicolumn{3}{|c|}{0.21} \\
\hline Word-of-mouth & \multicolumn{3}{|c|}{0.64} \\
\hline Price sensitivity & \multicolumn{3}{|c|}{0.33} \\
\hline Commitment & \multicolumn{3}{|c|}{0.21} \\
\hline Repeat purchasing behavior & \multicolumn{3}{|c|}{0.85} \\
\hline Relationship proneness & \multicolumn{3}{|c|}{0.26} \\
\hline
\end{tabular}


TABLE 3

Decomposition of Structural Effects

\begin{tabular}{|c|c|c|c|}
\hline & Direct & Indirect & Total \\
\hline $\begin{array}{l}\text { Effect on word-of-mouth } \\
\text { Consumer relationship proneness } \\
\text { Need for social affiliation }\end{array}$ & $\begin{array}{l}-0.26 \text { n.s. } \\
0.95^{* *}\end{array}$ & $\begin{array}{l}0.12 \text { n.s. } \\
-0.24 *\end{array}$ & $\begin{array}{l}-0.14 \text { n.s. } \\
0.71 * *\end{array}$ \\
\hline $\begin{array}{l}\text { Effect on price sensitivity } \\
\text { Consumer relationship proneness } \\
\text { Need for social affiliation }\end{array}$ & $\begin{array}{l}-0.12 \text { n.s. } \\
0.61 * *\end{array}$ & $\begin{array}{l}0.13^{*} \\
-0.19^{*}\end{array}$ & $\begin{array}{l}0.01 \text { n.s. } \\
0.42 * *\end{array}$ \\
\hline $\begin{array}{l}\text { Effect on repeat purchasing } \\
\text { Consumer relationship proneness } \\
\text { Need for social affiliation }\end{array}$ & $\begin{array}{l}-0.40 \text { n.s. } \\
0.99 \text { n.s. }\end{array}$ & $\begin{array}{l}0.20 \mathrm{n} . \mathrm{s} . \\
-.41 \mathrm{n} . \mathrm{s} .\end{array}$ & $\begin{array}{l}-0.20 \text { n.s. } \\
0.67 \text { n.s. }\end{array}$ \\
\hline
\end{tabular}

